\title{
ANALISIS INOVASI ADMINISTRASI GURU DALAM MENINGKATKAN MUTU PEMBELAJARAN (STUDI MAN REJANG LEBONG)
}

\section{ANAL YSIS OF TEACHER'S ADMINISTRATIVE INNOVATION IN IMPROVING THE INSTRUCTION QUALITY (CASE STUDY IN MAN REJANG LEBONG)}

\author{
Nuzuar, Idi Warsah \\ IAIN Curup, Bengkulu, Indonesia \\ Kelurahan Dusun Curup, Rejang Lebong, Bengkulu \\ e-mail:idiwarsah@iaincurup.ac.id
}

Naskah Diterima: 30 Juli 2018; Direvisi: 18 Oktober 2018; Disetujui: 03 Desember 2018

\begin{abstract}
This research was a descriptive research, conducted by using a quantitative approach. The research aimed to study the administrative innovation carried out by the teachers in MAN (Islamic Senior High School) Rejang Lebong and the obstacles faced by the teachers in conducting the innovation. Data was obtained by delivering questionnaires to 54 teachers in MAN Rejang Lebong. Questionnaires consisted of two parts, i.e.: 1) data regarding teacher's innovation and 2) data regarding teacher's obstacles in conducting the administrative innovation. Data was processed by using a percentage and a likert scale to determine the interval. The findings in this research explained that the teachers in MAN Rejang Lebong have conducted the administrative innovation. However, the innovation conducted has not been optimally done, i.e. 61,5\%, with a 62,15\% innovation on prota (annual program); a 61,67\% innovation on promes (semester program); a $58,72 \%$ innovation on syllabus; a $63,75 \%$ innovation on RPP (Lesson Plan). The obstacles that are interrupting the teachers in conducting the innovation, i.e. i) time constraint due to the teacher's tight performance schedule, ii) ever-changing curriculum, iii) the lack of carrying capacity, facilities, and infrastructure, iv) leadership, and v) technical guidance and administrative management.
\end{abstract}

Keywords: Innovation; Learning quality; Teachers administration

\begin{abstract}
Abstrak
Penelitian ini adalah penelitian deskriptif dengan pendekatan kuantitatif yang bertujuan untuk mengetahui inovasi administrasi yang dilakukan guru di MAN Rejang Lebong, dan hambatanhambatan apa saja yang dihadapi guru dalam melakukan inovasi administrasi tersebut. Data diperoleh dengan cara menyebarkan angket kepada 54 guru MAN Rejang Lebong. Angket terdiri dari dua yakni untuk mendapatkan data mengenai inovasi guru dan data mengenai hambatan guru dalam melakukan inovasi administrasi. Data diolah dengan persentase dan rumus skala likert untuk menentukan intervalnya. Temuan penelitian ini menunjukkan guru-guru MAN Rejang Lebong telah melakukan inovasi administrasi, akan tetapi inovasi yang dilakukakan belum maksimal, yaitu sebesar 61,57\%, dengan 62,15\% inovasi pada Prota, 61,67\% inovasi pada promes, 58,72\% inovasi pada silabus, dan 63,75\% inovasi pada RPP. Adapun faktor-faktor yang menghambat guru-guru tersebut dalam berinovasi yaitu keterbatasan waktu karena padatnya jadwal kinerja guru, kurikulum yang sering berubah, kurangnya daya dukung, sarana, dan prasarana, masalah kepemimpinan, dan kurangnya bimtek dan pengelolaan administrasi.
\end{abstract}

Kata kunci: Administrasi guru; Inovasi; Mutu pembelajaran 


\section{PENDAHULUAN}

Guru adalah ujung tombak dalam pencapaian tujuan pendidikan nasional karena pencapaian tujuan pendidikan nasional sebagaimana tertuang dalam pembukaan UUD 1945 alinea ke-4 yaitu mencerdaskan kehidupan bangsa, ${ }^{1}$ diawali dengan pencapaian tujuan pembelajaran yang dilakukan guru di kelas yang disebut dengan tujuan instruksional (tujuan pembelajaran) pada setiap pokok bahasan dan sub pokok bahasan yang diajarkan sesuai dengan kurikulum yang berlaku. Ketika tujuan instruksional (tujuan pembelajaran) tercapai dengan baik, maka akan menunjang pencapaian tujuan kurikuler, yaitu tujuan kurikulum yang diberlakukan. Tercapainya tujuan kurikuler dengan baik akan menunjang pencapaian tujuan institusional atau tujuan kelembagaan sesuai dengan jenis dan jenjang pendidikan. Selanjutnya ketika tujuan institusional tercapai dengan baik akan menunjang pencapaian tujuan nasional.

Berdasarkan uraian di atas, jelas bahwa pencapaian tujuan pendidikan nasional diawali dengan pencapaian tujuan instruksional yang dilakukan guru di kelas. Oleh karena itu, tidak berlebihan kalau dikatakan bahwa guru adalah ujung tombak pencapaian tujuan pendidikan. Untuk mencapai tujuan instruksional dengan optimal maka guru harus menyiapkan administrasi guru dalam bentuk perangkat pembelajaran.

Administrasi pembelajaran bagi guru sangat penting. Guru diharapkan mampu merancang pembelajaran dalam bentuk tertulis sebelum melakukan praktik mengajar di kelas. Kelengkapan administrasi pembelajaran sangat penting disiapkan guru agar pembelajaran yang dilakukan menjadi menyenangkan, dan mengundang siswa untuk aktif di dalamnya. Administrasi guru juga memuat perencanaan rinci mengenai apa-apa saja hal yang dilakukan oleh guru untuk mencapai tujuan pembelajaran. Oleh karena itu, administrasi pembelajaran sejatinya menunjang kesuksesan pencapaian tujuan belajar yang targetkan. Berpijak

\footnotetext{
${ }^{1}$ Kunandar. (2009). Guru Professional Implementasi Kurikulum Tingkat Satuan Pendidikan (KTSP) dan Sukses dalam Sertifikasi Guru. Jakarta: Rajawali Pres. hal. 5.
}

pada uraian diatas, dapat disimpulkan bahwa administrasi guru yang baik menentukan mutu pembelajaran.

Berdasarkan hasil pengamatan awal di Madrasah Aliyah Negeri (MAN) Rejang Lebong, ditemukan bahwa masih terdapat guru yang membuat administrasi pembelajaran yang kurang baik, padahal administrasi pembelajaran merupakan Tugas dan Fungsi Pokok (TUPOKSI) guru. Terkesan bahwa administrasi guru yang dibuat hanya merupakan kelengkapan administrasi guru untuk kepentingan ketika ada supervisi yang dilakukan oleh pengawas (Supervisor), sehingga administrasi guru tersebut merupakan administrasi guru dari masa ke masa, maksudnya administrasi guru tersebut tidak mengalami perubahan dan revisi sesuai dengan kebutuhan siswa. Ditambah lagi, dunia pendidikan terus berkembang seiring dengan kemajuan ilmu pengetahuan dan teknologi, dan kebijakan pemerintah dalam pendidikan juga selalu diperbaharui. Oleh karena itu, administrasi guru yang mencerminkan pengajaran yang dilakukan guru untuk memfasilitasi pembelajaran siswa haruslah selalu mengalami inovasi. Inovasi itu antara lain terkait dengan model pembelajaran, metode pembelajaran, media pembelajaran, evaluasi pembelajaran, dan lain-lain. Inovasi guru sebenarnya bisa terlihat dari administrasi guru yang memuat informasi detail mengenai tujuan pembelajaran, pendekatan/model/ strategi/teknik pembelajaran, materi pembelajaran, dan hal penting lainnya hingga evaluasi pembelajaran.

Untuk mengetahui kondisi sebenarnya tentang inovasi administrasi yang dibuat oleh guru dalam rangka mengoptimalkan pencapaian tujuan pembelajaran di sekolah, penulis melakukan penelitian secara seksama dengan rumusan tujuan masalah sebagai berikut: 1) untuk mengetahui inovasi administrasi guru dalam meningkatkan mutu pembelajaran yang dilakukan guru di MAN Rejang Lebong; 2) untuk mengetahui hambatan-hambatan yang dihadapi guru dalam melakukan inovasi administrasi guru. Peneliti berharap hasil penelitian ini dapat memberikan kontribusi baik secara teoretis maupun praktis: Secara teoritis hasil penelitian ini diharapkan 
dapat membantu mengatasi, memecahkan dan/ atau mencegah masalah minimnya inovasi adminitrasi guru di tingkat institusional. Secara praktis, 1) hasil penelitian ini diharapkan dapat dijadikan acuan bagi guru dalam meningkatkan inovasi administrasi guru yang nantinya akan berdampak pada meningkatnya mutu pembelajaran di sekolah khususnya pada MAN Rejang Lebong; 2) penelitian diharapkan dapat memberi masukan dalam pengembangan kebijakan terkait dengan mutu pendidikan pada umumnya dan khususnya mutu pembelajaran di MAN Rejang Lebong.

\section{Administrasi Guru}

Menurut Mulyasa, administrasi guru yang merupakan perencanaan pengajaran adalah suatu pedoman kerja untuk melaksanakan tugas guru sebagi pendidik dan sebagai pedoman belajar yang bisa digunakan sebagai pemandu siswa dalam belajar. ${ }^{2}$ Administrasi guru sangat penting karena dalam proses belajar mengajar, guru dituntut dapat melaksanakan proses pengajaran dengan baik sehingga dapat mencapai tujuan pengajaran seperti yang telah direncanakan. Hal ini sejalan dengan argumen Majid yang meyatakan bahwa salah satu penyebab proses belajar mengajar tidak berjalan dengan efektif karena kurangnya persiapan guru dalam mengajar termasuk juga pembuatan perencanaan pengajaran yang mengakibatkan tidak maksimalnya pencapaian tujuan pengajaran. ${ }^{3}$ Berpijak pada pernyataan Majid ini, dapat disimpulkan bahwa berkas administrasi guru merupakan panduan dalam mengendalikan pembelajaran dan peserta didik sehingga tercapainya tujuan pembelajaran yang tentunya berimbas pada mutu pembelajaran di sekolah.

Administrasi guru yang utama meliputi empat berkas yang harus dibuat guru setiap periode tertentu, yaitu Program Tahunan (PROTA), Program Semester (PROMES),

\footnotetext{
${ }^{2}$ Mulyasa, E. (2006). Menjadi Guru Profesional Menciptakan Pembelajaran Kreatif dan Menyenangkan. Bandung: Remaja Rosdakarya. hal. 213.

${ }^{3}$ Majid, A. (2005). Perencanaan Pembelajaran dan Mengembangkan Standar kompetensi guru. Bandung: Remaja Rosda Karya. hal. 4.
}

silabus, dan Rencana Pelaksanaan Pembelajaran (RPP) yang dibuat untuk setiap pertemuan. ${ }^{4}$ Gambar 1 menunjukkan alur berkas administrasi yang perlu diengkapi oleh guru.

Berdasarkan Gambar 1 diketahui bahwa guru berkewajiban mengembangkan kurikulum dengan memperhatikan pemetaan $\mathrm{KD}$ dan minggu efektif. Kurikulum yang sudah ada tersebut dikembangkan menjadi prota dan prome. Kemudian dilanjutkan dengan permbuatan silabus, dan diakhiri dengan RPP yang merupakan perencanaan pembelajaran untuk setiap pertemuan tatap muka di dalam kelas.

\section{Inovasi Administrasi Guru}

Inovasi menurut Kamus Besar Bahasa Indonesia (KBBI) adalah sebuah pembaharuan/ penemuan sesuatu yang baru dan berbeda dengan yang sudah ada sebelumnya. ${ }^{5}$ Sementara, menurut Purwanto, kata inovasi memliki pengertian sebagai suatu ide baru, cara baru, objek baru, atau penemuan baru yang dianggap baru oleh individu, kelompok, maupun sistem sosial. ${ }^{6}$ Sejalan dengan pengertian inovasi dari Purwanto, Mas'ud menambahkan bahwa inovasi ialah suatu ide, barang, kejadian, metode yang dirasakan atau diamati sebagai suatu hal yang baru bagi seseorang atau sekelompok orang (masyarakat), baik itu berupa hasil invention maupun diskoveri. Inovasi diadakan untuk mencapai tujuan tertentu atau untuk memecahkan suatu masalah tertentu. ${ }^{7}$.

${ }^{4}$ Amani, L., Dantes, N., \& I. W. Lasmawan. (2013). Implementasi Supervisi Klinis dalam Rangka Meningkatkan Kemampuan Guru Mengelola Proses Pembelajaran pada Guru SD Se-Gugus VII Kecamatan Sawan. PENDASI: Jurnal Pendidikan Dasar Indonesia, (3)1.

${ }^{5}$ Hasan, M. (2015). Inovasi dan Modernisasi Pendidikan Pondok Pesantren. KARSA: Journal of Social and Islamic Culture, 23(2).

${ }^{6}$ Purwanto. (2000). Difusi Inovasi. Jakarta: STIA-LAN PRESS. hal. 4.

${ }^{7}$ Udin Saefudin Sa'ud. (2008). Inovasi Pendidikan. Bandung: Alfabeta. hal. 3. 


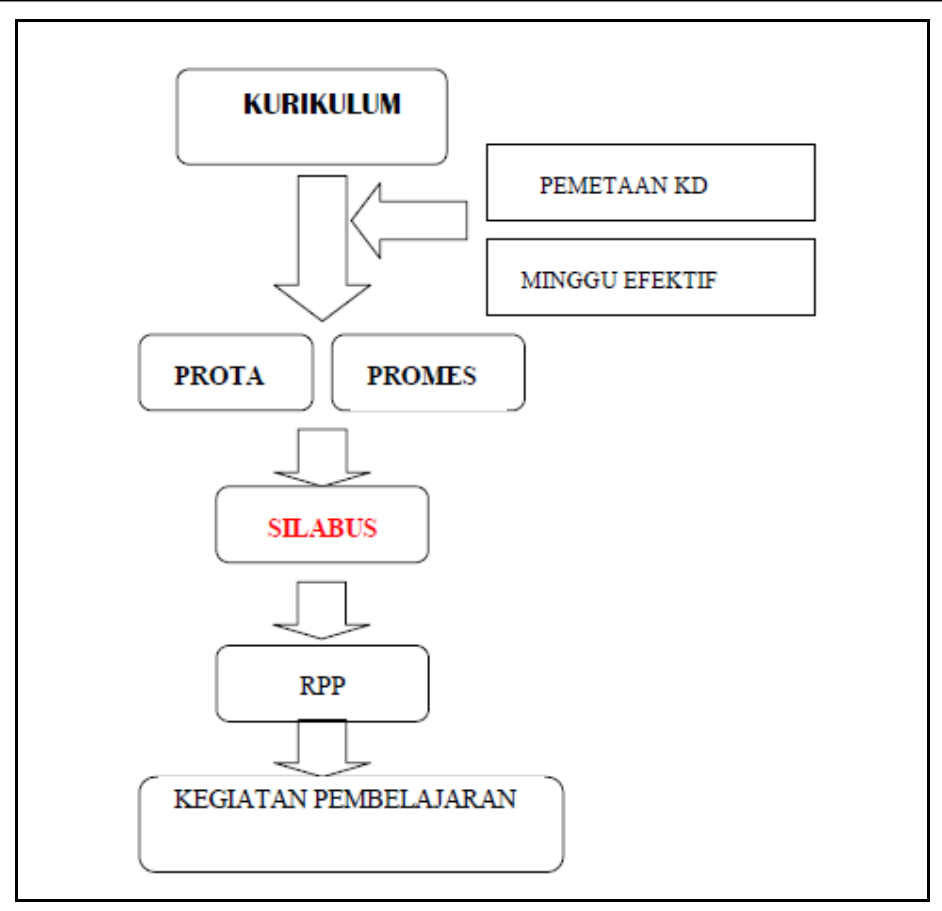

Gambar 1. Administrasi guru

Berdasarkan Gambar $1^{8}$ disimpulkan bahwa guru berkewajiban mengembangkan kurikulum dengan memperhatikan pemetaan $\mathrm{KD}$ dan minggu efektif. Kurikulum yang sudah ada tersebut dikembangkan menjadi Prota dan Promes. Kemudian dilanjutkan dengan permbuatan silabus, dan diakhiri dengan RPP yang merupakan perencanaan pembelajaran untuk setiap pertemuan tatap muka di dalam kelas.

\section{Inovasi Administrasi Guru}

Menurut Purwanto, kata inovasi memliki pengertian sebagai suatu ide baru, cara baru, objek baru, atau penemuan baru yang dianggap baru oleh individu, kelompok, maupun sistem sosial. ${ }^{9}$ Sejalan dengan pengertian inovasi dari Purwanto, Mas'ud menambahkan bahwa inovas adalah suatu ide, barang, kejadian, metode yang dirasakan atau diamati sebagai suatu hal yang baru bagi seseorang atau sekelompok orang (masyarakat), baik itu

${ }^{8}$ C. Lise. (2017). Unit 8: Silabus mata pelajaran. http://educloud.fkip.unila.ac.id/inde x.php?dir=Ilmu\%20Pendidikan/Pendidikan\%2 0Guru\%20Sekolah\%20Dasar/Pengembangan\% 20Kurikulum/\&file=pengembangan_kurikulu m_8.pdf.

${ }^{9}$ Purwanto. (2000). Difusi Inovasi. Jakarta: STIA-LAN PRESS. hal. 4. berupa hasil invention maupun diskoveri. Inovasi diadakan untuk mencapai tujuan tertentu atau untuk memecahkan suatu masalah tertentu. $^{10}$

Berpijak pada uraian di atas, dapat disimpulkan bahwa inovasi adalah pembaharuan yang sejatinya ditujukan untuk memecahkan permasalahn tertentu. Oleh karena itu, inovasi administrasi guru dapat diartikan sebagai pembaharuan-pembaharuan yang dilakukan guru dalam mendesain administrasi guru yang mencakup prota, promes, silabus, dan rpp yang bertujuan utuk memecahkan masalah-masalah yang terjadi dalam pembelajaran sekaligus mengikuti arus perkembangan teknologi, informasi dan pembaharuan kebijakan pendidikan yang dilakukan pemerintah. Inovasi dalam administrasi guru meliputi bagaimana guru mempersiapkan materi untuk pembelajaran yang dapat mempersiapkan siswa menghadapi tantangan kehidupan modern, bagaimana guru meg-optimalkan fasilitas, sarana dan prasarana yang tersedia untuk mengoptimalkan pembelajaran, bagaiman mendesain metode dan strategi yang tepat agar proses pembelajaran menyenangkan dan bermanfaat, dan lain sebagainya. Hal-hal yang desebutkan diatas haruslah terkandung dalam administrasi

${ }^{10}$ Udin Saefudin Sa'ud. (2008). Inovasi Pendidikan. Bandung: Alfabeta. hal. 3. 
guru karena administrasi guru itu sendiri adalah perencanaan pem-belajaran yang akan dilakukan guru selama periode tertentu.

Druker dalam Danim berpendapat bahwa ada beberapa sumber yang menginisiasi pentingnya melakukan inovasi administrasi pendidikan. Berikut ini adalah sumber-sumber tersebut.

\section{Kondisi yang tidak diharapkan}

Inovasi perlu dilakukan karena adanya kondisi yang tidak sesuai dengan yang diharapkan, seperti mutu pendidikan yang rendah dan tidak sesuai harapan, capaian siswa yang dibawah standar, dan lain sebagainya. Kondisi yang tidak diharapkan ini adalah akibat dari adminitrasi yang tidak dikelola secara baik sehingga dibutuhkan inovasi untuk mengatasi masalah-masalah tersebut.Menurut Danim munculnya inovasi guru dalam proses pembelajaran didorong oleh beberapa hal sebagai berikut: ${ }^{11}$

Pertama, munculnya ketidakwajaran, seperti pemberian nilai yang tidak sesuai dengan hasil evaluasi, pelayanan administrasi tenaga kependidikan yang tidak prima, sehingga problem tersebut merangsang adminitrator untuk membuat sebuah keputusan yang inovatif dalam bidang administrasi pendidikan. Kedua, kebutuhan yang muncul dalam proses, seperti memunculkan ide baru yang tidak terpikirkan sebelumnya dalam memenuhi kebutuhan proses pendidikan. Ketiga, perubahan dalam struktur industri pasar. Inovasi yang mengekuti kebutuhan pasar global mendorong terjadinya perubahan kurikulum dan strategi dalam proses belajar yang awalnya teoretis menjadi lebih praktis. Keempat, kondisi demografis. Agar administrator dapat menemukan dan melakukan terobosan baru untuk mengantisipasi keterbatasan kondisi demografis sekolah, sekaligus menemukan kelebihan apa yang dapat dikembangkan dari kondisi geografis tersebut. Kelima, perubahan persepsi, suasana dan makna. Secara umum hal tersebut

${ }^{11}$ Danim, S. (2002). Inovasi Pendidikan dalam Upaya Peningkatan Profesionalisme Tenaga Kependidikan. Bandung: Pustaka Setia. Hal. 150. disebabkan oleh berbedaan penerima-an dan penafsiran antara individu atas informasi yang diterimanya dari lingkungan sekitar melalui media massa maupun sosial dan berdasarkan pengalaman langsung dilapangan pendidikan. Keenam, Pengetahuan baru. Setiap pendidik merupakan keniscayaan, artinya seorang guru sejatinya tidak pernah berhenti belajar. Bahkan guru masa kini harus sering melibatkan diri dalam penelitian ilmiah, menulis buku maupun jurnal pendidikanagar inovasi pembelajaran dapat disemakin bervariasi.

Berbeda halnya dengan pendapat Prasetyawan bahwa inovasi memiliki beberapa sifat perubahan yaitu: ${ }^{12}$ Pertama, penggantian (substitution), Inovasi dalam penggantian bisa saja penggantian pendekatan, materi, dan lainlain yang tidak sesuai lagi dengan perkembagan zaman. Kedua, perubahan (alternation), inovasi untuk melakukan berubahan terhadap komponen-komponen tertentu, seperti tugas guru yang hanya mengajar, juga harus bertugas menjadi guru pembimbing. Artinya, perubahan ini berusaha melakukan pemberdayaan sebagian komponen agar para guru menjadi merasa diberdayakan dengan baik. Ketiga, penambahan (addition), model inovasi ini sekadar penambahan komponen dan tidak ada penggantian atau perubahan. Kalaupun ada yang berubah, maka hal itu hanya dalam koridor komponen pada sistem yang masih dipertahankan. Keempat, penyusunan kembali (restructuring), usaha restrukturisasi dari berbagai komponen yang telah ada dalam sistem bertujuan agar mampu menyesuaikan diri dengan tuntutan dan kebutuhan. Kelima, penghapusan (elimination), inovasi melalui eliminasi merupakan metode untuk melakukan perubahan dengan menghilangkan atau pengurangan aspek-aspek dan komponen-komponen tertentu dalam cara-cara lama yang tidak sesuai dengan per-kembangan zaman. Keenam, penguatan (reinforcement), penguatan dimaksud bertujuan untuk memperkokoh atau memantapkan kemampuan atau pola dan cara-cara yang sebelumnya terasa lemah.

${ }^{12}$ Prastyawan, P. (2011). Inovasi Kurikulum dan Pembelajaran. Al Hikmah: Jurnal Studi Keislaman. 1(2). 
Inovasi pembelajaran yang dilakukan oleh seorang praktisi pendidikan dapat dimungkinkan akan menemui berbagai hambatan. Beberapa pakar memiliki berbagai pendapat yang berbeda mengenai faktor-faktor utama yang menjadi hambatan dalam proses inovasi guru. Pendapat pertama muncul dari Wahyudin dan Susilana yang mengemukakan bahwa ada tiga macam hambatan utama yang berpotensi muncul dalam proses inovasi, yaitu: ${ }^{13}$ Pertama, mental block barriers, maksudnya adalah hambatan-hambatan yang disebabkan oleh sikap mental, seperti: salah persepsi atau asumsi, cenderung berfikir negatif, cemas akanmengalami kegagalan, tidak mau mengambil resiko terlalu dalam, malas, saat ini berada pada comfort zone (wilayah "nyaman dan aman"), cenderung resisten/menolak perubahan, dan lain sebagainya. Kedua, hambatan yang sifatnya culture block. Artinya adalah hambatan yang berakar dari budaya, seperti: fanatisme terhadap tradisi sehingga merasa bersalah bila perubahan yang dibuat bertentangan dengan tradisi. Ketiga, Hambatan social block. Maksudnya adalah hambatan dari faktor sosial, seperti perbedaan suku dan agama atau ras, perbedaan sosial dan ekonomi, nasionalisme yang sempit, arogansi primodial, sehingga terjadi fanatisme kedaerahan yang berlebihan.

Lain halnya dengan pendapat Ibrahim dalam Dimyati \& Mudjion berpendapat bahwa ada enam faktor utama yang dapat menghambat suatu inovasi, yaitu: Pertama, Estimasi yang tidak tepat. Inovasi sering kali gagal disebabkan oleh tidak matangnya perkiraan atas kemungkinan-kemungkinan yang mungkin muncul. Hambatan yang disebabkan oleh hal ini antara lain: kurang adanya pertimbangan implementasi inovasi, kurang adanya hubungan antar tim pelaksana, kurang adanya kesamaan pendapat tentang tujuan yang ingin dicapai, tidak adanya koordinasi antar petugas yang terlibat, dan

${ }^{13}$ Dinn Wahyudin \& Rudi Susilana. (2017). Inovasi Pendidikan dan pembelajaran: Materi 9 Kurikulum Pembelajaran. http://file. upi.edu/Direktori/FIP/JUR._PEND._LUAR_B IASA/196209061986011-HMAD_MULYADI PRANA/PDF/Inovasi_Pendidikan_Pembelajar an.pdf lain-lain. Kedua, Konflik dan motivasi. Konflik dalam proses inovasikemungkinan terjadi, contohnyaterjadisilang pendapat antara anggota tim, saling mencurigai dan timbul iri hari dari anggota tim inovasi. Selain itu, faktor lain yaitu lemahnya motivasi tim inovasi karena kesenjangan dalam pembagian kerja dan lain-lain.

Ketiga, inovasi tidak berkembang. Beberapa faktor yang dapat mempengaruhi inovasi yang dilakukan tidak berkembang seperti, pendapat yang rendah, faktor geografis, kurangnya sarana komunikasi, iklim dan cuaca yang tidak mendukung dan lain sebagainya. Keempat, masalah finansial. Inovasi sering terhambat karena dana yang tidak memadai. Terdapat beberapa faktor yang dapat menyebabkan masalah finansial ini adalah, bantuan dana yang sangat minim dan lambat, serta kondisi ekonomi masyarakat secara kurang baik. Kelima, Penolakan dari kelompok tertentu. Inovasi yang dilakukan akan dapat juga ditentukan oleh kesungguhan dan peranan seluruh kelompok masyarakat, khususnya kelompok masyarakat yang menentukan seperti golongan elit dan tokoh masyarakat. Tatkala terjadi penolakan dari kelompok masyarakat tersebut terhadap suatu inovasi, maka proses inovasi akan mengalami ganjalan. Penolakan inovasi sering ditunjukkan oleh kelompok sosial yang tradisional dan konservatif. Keenam, kurang adanya hubungan sosial. Faktor yang tidak kalah penting harus dipertimbangkan oleh innovator adalah kurangnya hubungan sosial yang baik antara berbagai pihak khususnya antar anggota team, sehingga terjadi ketidak harmonisan dalam bekerja. ${ }^{14}$

Berdasarkan ragam teori di atas, pelaksanan inovasi administrasi yang dilakukan oleh guru dalam meningkatkan mutu pembelajaran dalam proses pendidikan dapat berpijak pada teori di atas sebagaimana dideskripsikan pada Gambar 2.

Gambar 2 memberikan gambaran bahwa administrasi guru yang wajib dibuat adalah program tahunan, program semester, silabus

${ }^{14}$ Dimyati, Mudjiono. (2002). Belajar dan Pembelajaran. Jakarta: Rineka Cipta. hal. 5 . 
dan RPP. Administrasi guru tersebut tentu harus dilakukan inovasi pada setiap akhir semester. Inovasi ditandai dengan pergantian, perubahan, penambahan, penghapusan dan atau penguatan. Tentu dalam melakukan inovasi guru mungkin akan menemui hambatan, seperti mental block barriers, culture block dan hambatan yang bersifat sosial block. Bahkan pendapat lain mengungkapkan bahwa hambatan yang ditemui guru dalam berinovasi dapat berupa estimasi yang tidak tepat, inovasi tidak berkembang, masalah finansial yang dihadapi oleh guru, kurang diterimanya/penolakan dari kelompok tertentu dan kurang adanya hubungan sosial.

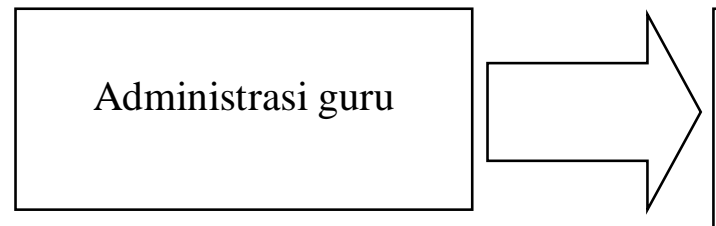

1. Program Tahunan (Prota)

2. Program Semester (Promes)

3. Silabus

4. RPP
1. Pergantian (Subtitution)

2. Perubahan (Alternation)

3. Penambahan (addition)

4. Penghapusan (deletion)

5. Penguatan (Reinforcement)

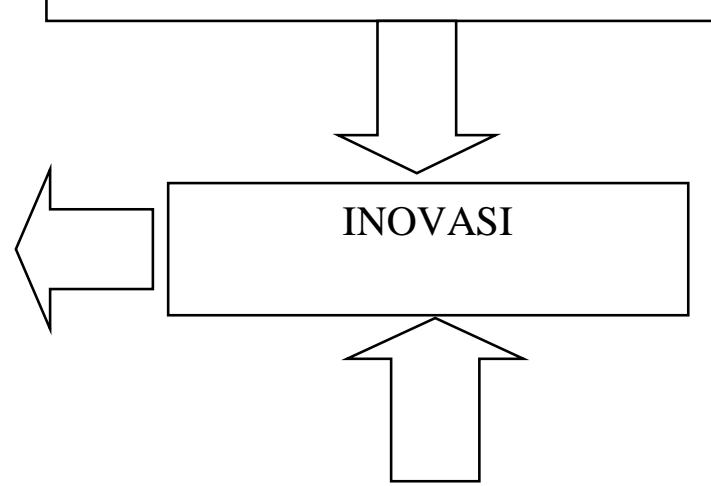

Permasalahan atau hambatan yang mungkin dihadapi oleh guru
Menurut Wahyudin dan Susilana:
1. Mental block barriers
2. Hambatan yang bersifat culture block
3. Hambatan yang bersifat sosial block
Menurut Dimyanti dan Mudjiono:
1. Estimasi yang tidak tepat
2. Konflik dan motivasi
3. Inovasi tidak berkembang
4. Masalah finansial
5. Penolakan dari kelompok tertentu
6. Kurang adanya hubungan sosial

Gambar 2. Teori pelaksanan inovasi administrasi yang dilakukan oleh guru

\section{METODOLOGI PENELITIAN}

Penelitian ini bertujuan untuk mendeskripsikan inovasi administrasi guru terhadap mutu pembelajaran di MAN Rejang Lebong dan hambatan apa saja yang mereka temui dalam berinovasi. Jenis penelitian ini adalah field research yang besifat deskriptif kuantitatif yaitu metode penelitian yang data penelitianya berupa angka-angka dan analisis menggunakan statistik" 15 Menurut Arikunto,

${ }^{15}$ Sugiyono. (2009). Metode Penelitian Kualitatif dan Kuantitatif dan $R \quad \& \quad D$. Bandung: Alfabeta. hal. 7. penelitian deskriptif didesain untuk mendapatkan informasi mengenai phenomena tertentu. ${ }^{16}$ Terlebih lagi, Zuriyah mengemukakan bahwa metode deskriptif adalah sebuah penelitian yang berfokus untuk menjelaskan situasi atau kondisi populasi tertentu secara sistematis, faktual, dan akurat. ${ }^{17}$ Berdasarkan pendapat

${ }^{16}$ Suharsimi Arikunto. (2002). Prosedur Penelitian: Suatu Pendekatan Praktek. Jakarta: Rineka Cipta. hal. 128.

${ }^{17}$ Nurul Zuriyah. (2000). Metodology Sosial dan Pendidikan: Teori Aplikasi. Jakarta: Bumi Aksara, hal. 20. 
para pakar diatas, dapat disimpulkan bahwa penelitian ini adalah penelitian deskriptif, karena berupaya mencari penjelasan mengenai inovasi guru MAN Rejang Lebong beserta hambatan-hambatan yang ditemui, yang nantinya akan dijelaskan dengan mempresentasikan angka-angka dari angket.

Penelitian ini dilakukan di MAN Rejang Lebong. Terletak di Jalan Letjen Suprapto No. 81 Talang Rimbo Baru, Curup, dipimpin oleh Bapak Drs. Sayidina Ali, M.Pd. Sekolah ini saat ini memiliki siswa sejumlah 830 orang, dengan tenaga guru 58 orang, dan staf TU berjumlah 17 orang. Populasi adalah keseluruhan subjek penelitian. ${ }^{18}$ Artinya menjadi populasi penelitian disini adalah semua guru MAN Rejang Lebong. Populasi guru MAN Rejang Lebong adalah sejumlah 58 orang. Menurut Arikunto, sampel adalah sebagian atau wakil dari populasi yang diteliti. ${ }^{19}$ Dalam penarikan sampel, peneliti berpedoman dengan pendapat Arikunto, jika populasi dibawah 100 maka semua dijadikan sampel dan jika lebih dari 100 maka dari populasi penelitian yang ada tersebut ambil jumlah populasi yang mendekati penentuan jumlah sampel dari populasi tertentu dengan taraf kesalahan $1 \%$, $5 \%$, dan $10 \%$. Mengingat populasi dalam penelitian ini sejumlah 58 orang, maka diputuskan untuk mengambil total sampel, yang artinya semua populasi dilibatkan sebagai sampel penelitian ini.

Teknik pengumpulan data pada penelitian ini adalah: Pertama, Angket yang digunakan terdiri dari dua angket. Angket yang pertama dibuat untuk memperoleh data inovasi administrasi guru. Angket kedua didesain untuk mengetahui hambatan-hambatan yang ditemui guru dalam berinovasi. Oleh karena itu, peneliti menyebar angket penelitian pada responden sesuai dengan kebutuhan yang akan diteliti. Skala pengukuran atau jenis angket yang digunakan adalah jenis angket skala likert. Sugiyono mengatakan bahwa, skala likert digunakan untuk mengukur sikap, pendapat, dan persepsi seseorang atau sekelompok orang tentang fenomena sosial. Dalam penelitian, fenomena sosial ini telah

\footnotetext{
${ }^{18}$ Arikunto, Prosedur Penelitian, hal. 108

${ }^{19}$ Arikunto, Prosedur Penelitian, hal. 109
}

ditetapkan secara spesifik oleh peneliti, yang selanjutnya disebut sebagai variabel penelitian. ${ }^{20}$

Skala likert dalam angket bisa digunakan pernyataan atau pertanyaan dengan menggunakan bentuk pilihan ganda dan bentuk checklist, maka angket yang digunakan dalam penelitian ini dalam bentuk checklist karena lebih praktis. Bentuk skala likert yang digunakan untuk angket pertama adalah dengan bentuk frekuensi yang terdiri dari 5 pilihan jawaban yaitu: Selalu (S) diberi nilai 5, Sering (Sr) diberi nilai 4, Kadang-kadang (Kd) diberi nilai 3, Jarang (Jr) diberi nilai 2, Tidak pernah (Tp) diberi nilai 1.

Sementara itu, untuk angket mengenai hambatan yang dialami guru dalam invovasi administrasi, digunakan skala likert yang menyatakan sikap yang terdiri dari 5 pilihan jawaban yaitu: Sangat setuju (SS), setuju (S), ragu-ragu (R), kurang Setuju (KS), tidak Setuju (TS). Terdapat dua jenis pernyataan dalam skala ini yaitu pernyataan positif $(\mathrm{F})$ dan negatif $(\mathrm{N})$. Pernyataan positif yaitu pernyataan yang berisi tentang hal-halyang positif mengenai obyek sikap. Sebaliknya pernyataan negatif adalahpernyataan yang berisi hal-hal yang negatif mengenai obyek sikap, yaitu bersifat tidak mendukung ataupun kontra terhadap obyek sikap yang diungkap. Pernyataan yang positif pilihan jawaban skornya antara lain SS diberi nilai $5, \mathrm{~S}$ nilai 4, $\mathrm{R}$ diberi nilai 3, TS diberi nilai 2 dan STS diberi nilai 1 . Sedangkan untuk pernyataan yang negatif dilakukan pembalikan skor.

Kedua angket yang digunakan dikembangkan dari teori-teori yang telah dibahas di bab dua, yang kemudian menjadi indikator untuk setiap butir pernyataan angket. Perumusan indikator menjadi butir-butir pernyataan dibuat blueprint (cetak biru) instrumen dibuat angket.

Kedua, Wawancara. Menurut Sugiono, tujuan mewawancarai seseorang adalah untuk mendapatkan informasi yang lebih lengkap dan mendalam dari responden. ${ }^{21}$ Wawancara dalam penelitian ini diberikan sebagai follow up bagi responden yang menjawab pertanyaan open-

${ }^{20}$ Sugiyono, Metode Penelitian, hal. 22

${ }^{21}$ Sugiyono, Metode Penelitian, hal. 137 
ended yang ada di dalam angket untuk menggali informasi lebih mendalam mengenai inovasi administrasi guru dan hambatan yang dialami dalam melaksanakan inovasi tersebut. Oleh karena itu, sampel yang diinterview adalah sampel yang menjawab iya pada item open-ended di angket saja.

Sementara teknik analisis data penelitian ini adalah dengan analisis data kuantitatif dengan mengikuti langkah-langkah sebagai berikut: 1) Langkah pertama dalam menganalisis data adalah mengelompokkan jawaban-jawaban siswa kedalam kategori yang sama; 2) Kemudian, peneliti menghitung jumlah frekuensi jawaban guru di tiap butir pernyataan berdasarkan angket. Dalam penelitian ini, dalam perhitungan jumlah frekuensi jawaban guru, digunakan skala untuk setiap opsi seperti yang telah dijelaskan di bagian sebelumnya; 3) Peneliti menghitung skor total frekuensi angket pertama untuk mengetahui inovasi administrasi guru dengan menggunakan formula berikut:

$$
X=((\mathbf{S} \times 5)+(\mathbf{f} \operatorname{Sr} \times 4)+(\mathbf{f} \mathbf{K d} \times 3)+(\mathbf{f} \mathbf{J} \times 2)+(\mathbf{f} \mathbf{T p} \times 1))
$$

Keterangan:
f S : Frekuensi guru yang menjawab selalu
$\mathrm{f} \mathrm{Sr} \quad$ : Frekuensi guru yang menjawab sering
$\mathrm{f} \mathrm{Kd} \quad$ : Frekuensi guru yang menjawab kadang-kadang
$\mathrm{f} \mathrm{Jr} \quad$ : Frekuensi guru yang menjawab jarang
f Tp : Frekuensi guru yang menjawab tidak pernah

Sementara itu, untuk angket kedua invovasi administrasi digunakan formula mengenai hambatan yang dialami guru dalam berikut untuk pernyataan positif:

$$
\mathbf{X}=((\mathbf{f} \mathbf{S S} \times \mathbf{5})+(\mathbf{f} \mathbf{S} \times \mathbf{4})+(\mathbf{f} \mathbf{R} \times \mathbf{3})+(\mathbf{f} \mathbf{K S} \times 2)+(\mathbf{f} \mathbf{T S} \times 1))
$$

\section{Keterangan:}

$\begin{array}{ll}\text { f SS } & \text { : Frekuensi guru yang menjawab sangat setuju } \\ \text { f S } & \text { :Frekuensi guru yang menjawab setuju } \\ \text { f R } & \text { : Frekuensi guru yang menjawab ragu-ragu } \\ \text { f KS } & \text { : Frekuensi guru yang menjawab kurang setuju } \\ \text { f TS } & \text { : Frekuensi guru yang menjawab tidak setuju }\end{array}$

Sedangkan untuk pernyataan yang setiap butir angket berdasarkan jawaban guru negatif dilakukan pembalikan skor. Langkah di angket dengan menggunakan formula berikutnya adalah menghitung persentase berikut:

$$
\mathrm{P}=\frac{\text { Enilai }}{\text { nilaimaksimal }} \times 100 \%
$$

Setelah diperoleh persentasi jawaban guru melalui formula di atas, lalu langkah selanjutnya adalah menganalisis hasil hitung angket dan hasil wawancara.

\section{HASIL DAN PEMBAHASAN}

Guru-guru MAN Rejang Lebong telah melakukan inovasi administrasi, akan tetapi inovasi yang dilakukakan belum maksimal, yaitu sebesar 61,57, dengan 62,15\% inovasi pada Prota, $61,67 \%$ inovasi pada Promes, $58,72 \%$ inovasi pada silabus, dan $63,75 \%$ inovasi pada RPP. Berdasarkan data yang diperoleh, ditemukan juga guru yang tidak melakukan inovasi. Persentasi inovasi administrasi yang dilakukan guru MAN Rejang Lebong yang tertinggi di RPP, dan terendah di silabus. Inovasi administrasi yang dilakukan oleh guru MAN Rejang Lebong pada Prota, Promes, dan RPP jatuh pada interval Sering (61-80\%). Sementara itu, inovasi pada silabus masuk dalam kategori interval Kadang-kadang (41-60\%). Selain itu, ditemukan juga guru yang telah memanfaatkan 
teknologi untuk berinovasi dalam administrasi guru.

Guru-guru MAN Rejang Lebong bersikap netral bahkan kurang setuju dengan faktor-faktor yang menghambat inovasi administrasi yang di kemukakan oleh Wahyudian dan Susilana, dan Dimyanti dan Mujiono. Responden ragu-ragu atau bersifat netral mengenai apakah terhambatnya inovasi dikarenakan salah persepsi atau asumsi, karena saat ini berada dalam comfort zone, adat yang sudah mengakar dan mentradisi, ketaatan terhadap tradisi setempat, perbedaan suku, agama, atau ras, perbedaan sosial ekonomi, estimasi yang tidak tepat, inovasi yang tidak berkembang, masalah finansial, dan penolakan dari kelompok tertentu. Sementara itu, responden kurang setuju kalau perasaanperasaan negatif sepertikecenderungan berpikir negatif, dihantui kecemasan/kegagalan, tidak mau mengambil resiko, malas, cenderung menolak perubahan, ada perasaan berdosa/ bersalah bila berubah menjadi hambatan dalam melaksanakan inovasi. Mereka juga beranggapan kurang setuju bahwa konflik, motivasi, dan kurang adanya hubungan sosial menjadi kendala dalam inovasi administrasi. Guru-guru MAN Rejang Lebong berpendapat bahwa ada faktor lainnya yang menghambat mereka dalam berinovasi, yaitu faktor keterbatasan waktu karena padatnya jadwal kinerja guru, kurikulum yang sering berubah, kurang adanya daya dukung, sarana, prasarana, masalah kepemimpinan, dan kurangnya bimtek dan pengelolaan administrasi.

\section{Analisis Inovasi Administrasi Guru}

Tabel 1 adalah rangkuman hasil analisis inovasi administrasi guru dalam meningkatkan mutu pembelajaran pada MAN Rejang Lebong.

Tabel 1. Persentase Inovasi yang dilakukan Responden dalam Administrasi Guru

\begin{tabular}{ccc}
\hline No & Jenis administrasi guru & Rata-rata index persentase \\
\hline 1 & Prota & 62,15 \\
2 & Promes & 61,67 \\
3 & Silabus & 58,72 \\
4 & RPP & 63,75 \\
\hline \multicolumn{2}{c}{ Rata-rata index persentase } & 61,57 \\
\hline
\end{tabular}

Berdasrkan Tabel 1 didapatkan data dengan range yang tidak jauh berbeda. Dengan persentasi inovasi tertinggi di RPP, dan terendah di silabus. Inovasi administrasi yang dilakukan oleh guru MAN Rejang Lebong pada prota, promes, dan RPP jatuh pada interval Sering (61-80\%). Sementara itu, inovasi pada silabus masuk dalam kategori interval Kadang-kadang (41-60\%).

Berdasarkan data yang telah disajikan diatas, dapat ditarik kesimpulan bahwa sebagian besar guru-guru MAN Rejang Lebong telah melakukan inovasi administrasi, akan tetapi inovasi yang dilakukakan belum maksimal. Berdasarkan data yang diperoleh, memang ada beberapa guru yang tidak pernah melakukan inovasi, tapi jumlahnya tidak banyak.
Sementara itu dari hasil wawancara ke sejumlah guru, peneliti mendapatkan beberapa data tambahan. Responden 12 menyatakan bahwa beliau juga melakukan inovasi pada RPP dengan menambahkan remidial dan pengayaan bagi slow learner. Selain itu, ada dua guru MAN Rejang Lebong yang telah menggunakan teknologi dalam administrasi. Responden 19 mengubah absen dan penilaian siswa dalam bentuk software handphone, dan responden 47 mengaku selalu mengambil sumber belajar dari instagram, video, Whatsapp (WA), dan platform lainnya.

\section{Analisis hambatan yang dihadapi guru dalam melakukan inovasi administrasi}

Hasil analisis data mengenai hambatan yang dihadapi guru dalam melakukan inovasi administrasi dapat dilihat pada Tabel 2. 
Tabel 2. Data Index/Persentase tiap Item Faktor Penghambat

\begin{tabular}{|c|c|c|c|c|c|c|c|c|}
\hline No. & Hambatan-hambatan & SS & $\mathrm{S}$ & $\mathrm{R}$ & $\mathrm{KS}$ & $\mathrm{TS}$ & Total & Index/persentase \\
\hline 1 & Salah persepsi atau asumsi & 30 & 28 & 30 & 28 & 17 & 133 & 49,26 \\
\hline 2 & Cenderung berpikir negatif & 20 & 16 & 3 & 34 & 28 & 101 & 37,41 \\
\hline 3 & $\begin{array}{l}\text { Dihantui } \\
\text { kecemasan/kegagalan }\end{array}$ & 10 & 8 & 21 & 28 & 29 & 96 & 35,56 \\
\hline 4 & $\begin{array}{l}\text { Tidak mau mengambil } \\
\text { resiko }\end{array}$ & 10 & 16 & 9 & 54 & 18 & 107 & 39,63 \\
\hline 5 & Malas & 35 & 12 & 0 & 16 & 36 & 99 & 36,67 \\
\hline 6 & $\begin{array}{l}\text { Saat ini berada dalam } \\
\text { comfort zone }\end{array}$ & 20 & 44 & 15 & 18 & 25 & 122 & 45,19 \\
\hline 7 & $\begin{array}{l}\text { Cenderung menolak } \\
\text { perubahan }\end{array}$ & 20 & 12 & 21 & 22 & 29 & 104 & 38,52 \\
\hline 8 & $\begin{array}{l}\text { Adat yang sudah mengakar } \\
\text { dan mentradisi }\end{array}$ & 20 & 36 & 15 & 38 & 17 & 126 & 46,67 \\
\hline 9 & $\begin{array}{l}\text { Taat terhadap tradisi } \\
\text { setempat }\end{array}$ & 5 & 36 & 15 & 40 & 19 & 115 & 42,59 \\
\hline 10 & $\begin{array}{l}\text { Ada perasaan } \\
\text { berdosa/bersalah bila } \\
\text { berubah }\end{array}$ & 15 & 8 & 15 & 40 & 24 & 102 & 37,78 \\
\hline 11 & $\begin{array}{l}\text { Perbedaan suku, agama, } \\
\text { atau ras }\end{array}$ & 15 & 36 & 21 & 44 & 13 & 129 & 47,78 \\
\hline 12 & Perbedaan sosial ekonomi & 20 & 52 & 48 & 16 & 13 & 149 & 55,19 \\
\hline 13 & Estimasi yang tidak tepat & 25 & 28 & 21 & 44 & 13 & 131 & 48,52 \\
\hline 14 & Konflik & 20 & 8 & 9 & 26 & 32 & 95 & 35,19 \\
\hline 15 & Motivasi & 20 & 16 & 12 & 26 & 29 & 103 & 38,15 \\
\hline 16 & $\begin{array}{l}\text { Inovasi yang tidak } \\
\text { berkembang }\end{array}$ & 25 & 24 & 15 & 24 & 26 & 114 & 42,22 \\
\hline 17 & Masalah finansial & 40 & 16 & 18 & 16 & 28 & 118 & 43,7 \\
\hline 18 & $\begin{array}{l}\text { Penolakan dari kelompok } \\
\text { tertentu }\end{array}$ & 15 & 16 & 15 & 40 & 22 & 108 & 40 \\
\hline 19 & $\begin{array}{l}\text { Kurang adanya hubungan } \\
\text { sosial }\end{array}$ & 15 & 16 & 6 & 30 & 30 & 97 & 35,93 \\
\hline \multicolumn{8}{|c|}{ Total } & 795,9 \\
\hline \multicolumn{8}{|c|}{ Rata-rata } & 41,89 \\
\hline
\end{tabular}

Data persentase Gambar 2 diintepretasi berdasarkan kriteria interval. Interval untuk angket ini adalah 20 , mengikuti rumus $\mathrm{I}=$ $100 /$ jumlah skor (likert), maka $\mathrm{I}=100 / 5=20$. Oleh karena itu, kriteria intepretasi skornya adalah sebagai berikut:

$$
\begin{array}{ll}
0 \%-19,99 \% & =\text { Tidak Setuju } \\
20 \%-39,99 \% & =\text { Kurang Setuju } \\
40 \%-59,99 \% & =\text { Ragu-ragu (netral) } \\
60 \%-79,99 \% & =\text { Setuju } \\
80 \%-100 \% & =\text { Sangat Setuju }
\end{array}
$$

Jadi dapat disimpulkan bahwa responden ragu-ragu atau bersifat netral mengenai apakah terhambatnya inovasi dikarenakan salah persepsi atau asumsi, karena saat ini berada dalam comfort zone, adat yang sudah mengakar dan mentradisi, ketaatan terhadap tradisi setempat, perbedaan suku, agama, atau ras, perbedaan sosial ekonomi, estimasi yang tidak tepat, inovasi yang tidak berkembang, masalah finansial, dan penolakan dari kelompok tertentu. Sementara itu, responden kurang setuju kalau kecenderungan berpikir negatif menghambat inovasi mereka. Mereka juga kurang setuju jika perasaan-perasaan negatif seperti dihantui kecemasan/kegagalan, tidak mau mengambil resiko, malas, cenderung 
menolak perubahan, ada perasaan berdosa/ bersalah bila berubah menjadi hambatan dalam melaksanakan inovasi. Responden juga beranggapan tidak setuju bahwa konflik menghambat inovasi mereka. Selain itu, mereka juga kurang setuju jika kurangnya motivasi dan kurang adanya hubungan sosial menjadi faktor penghambat berinovasi.

Berdasarkan data dari wawancara kepada responden sebagai bentuk follow up angket yang telah disebarkan, khususnya untuk item pertanyaan terbuka, ditemukan beberapa faktor yang menghambat guru-guru MAN Rejang Lebong melakukan inovasi administrasi. Faktor pertama adalah keterbatasan waktu. Menurut responden 17, Inovasi administrasi sering terkendala waktu. Hal ini sejalan dengan pendapat dari responden lainnya, salah satunya responden 49 yang mengatakan bahwa padatnya jadwal kinerja guru terkadang membuat kurang fokus dengan urusan adminitrasi. Faktor yang kedua adalah kurikulum yang sering berubah. Menurut responden 20, 32, 34, kurikulum yang berubah-ubah membuat guru bingung. Faktor berikutnya adalah kurangnya fasilitas yang mumpuni. Menurut responden 8 , Inovasi jadi terhambat karena disebabkan kurang adanya daya dukung, sarana, prasarana, dll untuk menunjang berkembangnya sebuah inovasi yang mumpuni. Hal ini juga ditekankan lagi oleh responden 47. Selanjutnya responden 46 juga berpendapat bahwa hambatan yang dirasakan yaitu ketika pimpinan madrasah tidak memikirkan kualitas sekolah sebab hanya mengejar materi yang sebanyak-banyaknya, membuat inovasi guruguru dalam administrasi terhambat karena fasilitas seperti komputer, infokus, dll tidak ada. Pernyataan dari responden 46 juga sekaligus mengimplikasikan faktor kepemimpinan juga menjadi penghambat inovasi. Hal ini juga dibenarkan oleh responden 7, 29, dan 48. Faktor terakhir yang menghambat proses inovasi adalah kurangnya bimtek dan pengelolaan administrasi, sebagaimana dijelaskan oleh responden 50, bahwa mereka kesulian melakukan inovasi karena kurangnya bimtek dan pelatihan berkaitan dengan pengelolaan administrasi.

Berdasarkan uraian diatas, dapat disimpulkan bahwa responden bersikap netral, bahkan kurang setuju dengan faktor-faktor yang menghambat inovasi administrasi yang di kemukakan oleh Wahyudian dan Susilana, dan Dimyanti dan Mujiono. Responden malah memiliki alasan sendiri mengenai faktor yang menghambat inovasi administrasi, yaitu faktor keterbatasan waktu karena padatnya jadwal kinerja guru, kurikulum yang sering berubah, kurang adanya daya dukung, sarana, prasarana, masalah kepemimpinan, dan kurangnya bimtek dan pengelolaan administrasi.

\section{PENUTUP}

Kesimpulan yang diperoleh dari penelitian ini adalah Pertama, Guru-guru MAN Rejang Lebong telah melakukan inovasi administrasi, akan tetapi inovasi yang dilakukakan belum maksimal, yaitu sebesar 61,57 , dengan rincian a) $62,15 \%$ inovasi pada Prota; b) $61,67 \%$ inovasi pada Promes; c) $58,72 \%$ inovasi pada silabus, dan; d) $63,75 \%$ inovasi pada RPP. Kedua, Faktor penghambat dalam melakukan inovasi administrasi guru pada MAN Rejang Lebong adalah a) keterbatasan waktu karena padatnya jadwal kinerja guru; b) kurikulum yang sering berubah; c) kurang adanya daya dukung, sarana, prasarana; d) masalah kepemimpinan, dan d) kurangnya bimtek dan pengelolaan administrasi.

Berdasarkan kesimpulan di atas, penelitian ini memberikan saran kepada beberapa pihak: Pertama, untuk Guru, diharapkan kiranya untuk selalu melakukan inovasi terhadap administrasi guru dalam bentuk perangkat pembelajaran menyesuaikan dengan tuntutan perkembangan ilmu pengetahuan dan teknologi serta kurikulum yang berlaku. Kedua, untuk Kepala Sekolah, agar memperhatikan faktor-faktor yang menghambat inovasi administrasi guru yang telah ditemukan agar dapat memaksimalkan inovasi administrasi guru di MAN Rejang Lebong. Ketiga, untuk Pengawas, agar adalam melakukan supervisi secara berkala terhadap administrasi guru pada MAN Rejang Lebong.

\section{UCAPAN TERIMA KASIH}

Penulis mengucapkan banyak terima kasih kepada semua pihak yang telah memberikan kontribusi pada penelitian ini. 
Pertama kepada Kepala Puslitbang Pendidikan Agama dan Keagamaan, Badan Litbang dan Diklat, Kementerian Agama RI. Kedua kepeda LP2M IAIN Curup yang telah memberikan kesempatan untuk melakukan penelitian DIPA tahun 2017. Ketiga, kepada Kepala Sekolah MAN Rejang Lebong yang telah memberikan ijin kepada penulis untuk melakukan penelitian di sekolah tersebut, semua guru pendidikan agama Islam, tenaga kependidikan MAN Rejang Lebong, serta segenap siswa yang telah memberikan data dan informasi kepada penulis. Semoga penelitian ini dapat memberikan manfaat bagi semua pihat dalam rangka peningkatan mutu tenaga pendidik di MAN Rejang Lebong.

\section{DAFTAR PUSTAKA}

Amani, Luh, Nyoman Dantes, and I. Wayan Lasmawan. (2013). Implementasi Supervisi Klinis dalam Rangka Meningkatkan Kemampuan Guru Mengelola Proses Pembelajaran pada Guru SD Se-Gugus VII Kecamatan Sawan. PENDASI:Jurnal Pendidikan Dasar Indonesia. Vol. 3 Nomor. 1.

Arikunto, Suharsimi. (2002). Prosedur Penelitian: Suatu Pendekatan Praktek. Jakarta: Rineka Cipta.

Chasimijatin, Lise. (2017). Unit 8: Silabus mata pelajaran. http://educloud.fkip.uni la.ac.id/index. php?dir=Ilmu\%20Pendidi kan/Pendidikan\%20Guru\%20Sekolah\%2 0Dasar/Pengembangan\%20Kurikulum/\& file=pengembangan_kurikulum_8.pdf.

Danim, Sudarwan. (2002). Inovasi Pendidikan dalam Upaya Peningkatan Profesionalisme Tenaga Kependidikan. Bandung: Pustaka Setia.

Dimyati \& Mudjiono. (2002). Belajar dan Pembelajaran. Jakarta: Rineka Cipta.

Kunandar. (2009). Guru Professional Implementasi Kurikulum Tingkat Satuan Pendidikan (KTSP) dan Sukses dalam Sertifikasi Guru. Jakarta: Rajawali Pres.
Majid, Abdul. (2005). Perencanaan Pembelajaran dan Mengembangkan Standar kompetensi guru. Bandung: Remaja Rosda Karya.

Muhammad Hasan, (2015) Inovasi dan Modernisasi Pendidikan Pondok Pesantren. KARSA: Journal of Social and Islamic Culture Vol. 23 Nomor. 2.

Mulyasa, E. (2006). Menjadi Guru Profesional Menciptakan Pembelajaran Kreatif dan Menyenangkan. Bandung: Remaja Rosdakarya.

Mustofa, Ali. (2017). Implementasi Manajerial Kepala Madrasah dalam Pengelolaan Pembelajaran di Madrasah Ibtidaiyah Negeri Baru Pangkalan Bun.Tesis tidak diterbitkan, UIN Palangkaraya.

Prastyawan, P. (2011). Inovasi Kurikulum dan Pembelajaran. Al Hikmah: Jurnal Studi Keislaman Vol. 1 Nomor. 2

Purwanto. (2000). Difusi Inovasi. Jakarta: STIA-LAN PRESS

Sugiyono (2009). Metode Penelitian Kualitatif dan Kuantitatif dan $R \& D$. Bandung: Alfabeta.

Sa'ud, Udin Saefudin. (2008). Inovasi Pendidikan. Bandung: Alfabeta.

Wahyudin, Dinn \& Rudi Susilana. (2017). Inovasi Pendidikan dan pembelajaran: Materi 9 Kurikulum Pembelajaran. http://file.upi.edu/Direktori/FIP/JUR._PE ND._LUAR_BIASA/196209061986011HMAD_MULYADIPRANA/PDF/Inova si_Pendidikan_Pembelajaran.pdf.

Zuriyah, Nurul. (2000). Metodology Sosial dan Pendidikan: Teori Aplikasi. Jakarta: Bumi Aksara. 